\title{
Cystoderma adnatifolium and C. arcticum n.sp. in Spitzbergen
}

\author{
HARRI HARMAJA
}

\begin{abstract}
HARMAJA, H. 1984: Cystoderma adnatifolium and C. arcticum n.sp. in Spitzbergen. - Karstenia 24: 31-32.

Cystoderma adnatifolium (Peck) Harmaja (Agaricales: Tricholomataceae) is reported from Spitzbergen (Svalbard) for the first time. A new species, Cystoderma arcticum Harmaja, is described from Spitzbergen. It belongs to the group of $C$. fallax Smith \& Sing., but has larger spores than the other species of the group.
\end{abstract}

Harri Harmaja, Botanical Museum, University of Helsinki, Unioninkatu 44, SF-00170 Helsinki, Finland

During my revisory work on the genus Cystoderma Fayod (Agaricales: Tricholomataceae), I examined the material collected in Spitzbergen (Svalbard) by Finnish mycologists from Turku University. One of the two specimens, an unpublished record, represents C. adnatifolium (Peck) Harmaja, which has not been reported before from arctic or oroarctic areas. The other specimen represents an undescribed species of the $C$. fallax Smith \& Sing. group and will be described below as $C$. arcticum Harmaja. This specimen has been published as C. granulosum (Batsch: Fr.) Kühn. by Ohenoja (1971). Representatives of this genus are evidently infrequent in Spitzbergen; Ohenoja (1971) mentions only one earlier record from the area (likewise of $C$. granulosum).

Cystoderma adnatifolium (Peck) Harmaja

Specimen examined: Norway, Spitzbergen, Isfjorden, Longyearbyen, 1.VIII.1977 Paavo Kallio (TUR 72531).

\section{Cystoderma arcticum Harmaja, n.sp.}

Cystodermatis fallacis similis. Ab ea praecipue differt sporis distincte maioribus, $6.0-8.0(-10.0) \times 4.0-6.0$ $\mu \mathrm{m}$, non nec sclerosporis et sclerobasidiis dextrinoideis. E loco arctico collecta est. - Holotypus: Norway, Spitzbergen (Svalbard), Isfjorden, Longyerbyen, meadow below the village, 22.VIII.1966 Esteri Kankainen (now Ohenoja; TUR 69527).

The great majority of the spores are rather broadly ellipsoid, some being moderately ellipsoid and some subglobose-lacrymoid. Good non-collapsed spores are observed on the pileus surface, but they are found in variable amounts in the gills as well. This new species belongs to the group of $C$. fallax, differing from all the other species known in the group chiefly in its larger spores and the fact that minor proportions of the spores and basidia consist of conspicuous thick-walled somewhat dextrinoid sclerospores and sclerobasidia. Moreover, the other species of the group are mostly inhabitants of boreal and/or montane coniferous forests, none of them having been collected beyond or above the forest limit, while $C$. arcticum was collected in the middle arctic zone (cf. Eurola 1968). C. tuomikoskii Harmaja (Harmaja 1979) is closely related to C. arcticum, but its spores measure $5.2-7.2 \times 3.7-4.5 \mu \mathrm{m}$ and are slightly differently shaped, and its sphaerocysts are more coarsely encrusted, so that the pileus colour is darker. The dry pileus of $C$. arcticum is rusty brown, and the dry gills are devoid of a pink tinge (which is usually present in $C$. fallax).

Although the specimen of $C$. arcticum was published as C. granulosum, Ohenoja (1971) observed that it had a fairly distinct ring around the stipe and that the spores were larger than those of $C$. granulosum. On the other hand, the spore size was given as averaging only $6.2 \times 4.0 \mu \mathrm{m}$ and the spore wall was reported to be inamyloid. Afterwards the specimen has teen named as $C$. fallax, by Ohenoja herself.

It is probable that some of the records of $C$. fallax and C. amianthinum (Scop.) Konr. \& Maubl. from Iceland (Hallgrimsson 1973), the record of $C$. sp. from Alaska (Kobayasi et al. 1967), and the records of C. fallax and C. tuomikoskii from Alaska (Laursen \& Ammirati 1982) actually refer to C. arcticum.

\section{References}

Eurola, S. 1968: Über die Fjeldheidevegetation in den Gebieten von Isfjorden und Hornsund in Westspitzbergen. - Aquilo, Ser. Bot. 7: 1-56.

Hallgrimsson, H. 1973: Islenzkir hattsveppir 3. Lepiotaceae (Agaricaceae pro parte), Gomphidiaceae, Paxillasecie, Crepidotaceae. - Acta Bot. Islandica 2: 29-55. 
Harmaja, H. 1979: Studies in the genus Cystoderma. Karstenia 19: 25-29.

Kobayasi, Y., Hiratsuka, N., Korf, R.P., Tubaki, K., Aoshima, K., Soneda, M. \& Sugiyama, J. 1967: Mycological studies of the Alaskan Arctic. - Ann. Rep. Inst. Fermentation, Osaka 3: 1-138.

Laursen, G.A. \& Ammirati, J.F. 1982: The FISAM in retrospect. - In: Laursen, G.A. \& Ammirati, J.F. (eds.), Arctic and alpine mycology. The first international symposium on arcto-alpine mycology: 532-544. Seattle \& London.

Ohenoja, E. 1971: The larger fungi of Svalbard and their ecology. - Rep. Kevo Subarctic Res. Sta. 8: 122-147.

Accepted for publication on 2 February, 1984 